\title{
Knowledge, attitudes and practices of cervical cancer screening by health care providers in the Emana health area: Yaounde-Cameroon
}

\author{
Fouedjio Jeanne Hortence $^{1 *}$, Mawamba Sonfack Sophie ${ }^{2}$, Wandji Brigitte ${ }^{1}$, \\ Fouelifack Ymélé Florent ${ }^{3}$, Nangue Charlette ${ }^{2}$, Ngaroua ${ }^{2}$, Kemfang Ngowa Jean Dupont ${ }^{1}$
}

\begin{abstract}
${ }^{1}$ Department of Obstetrics and Gynecology, University of Yaoundé I, Cameroon
${ }^{2}$ Department of Biomedical Sciences, University of Ngaoundéré, Evangelic University Institute of Cameroon ${ }^{3}$ Department of Obstetrics and Gynecology University of Douala, Higher Institute of Medical Technologies of Nkolondom, Cameroon
\end{abstract}

Received: 02 March 2020

Accepted: 30 March 2020

*Correspondence:

Dr. Fouedjio Jeanne Hortence,

E-mail: fouedjiojeanne@yahoo.fr

Copyright: (C) the author(s), publisher and licensee Medip Academy. This is an open-access article distributed under the terms of the Creative Commons Attribution Non-Commercial License, which permits unrestricted non-commercial use, distribution, and reproduction in any medium, provided the original work is properly cited.

\section{ABSTRACT}

Background: Gynaecological cancers and more particularly those of the cervix cause many victims in our country despite the many prevention tools that exist. The objective of this study was to assess the knowledge, attitudes and practices of providers on cervical cancer in the Emana health area.

Methods: To achieve this objective, we conducted a cross-sectional study form the period from April $2^{\text {nd }}$ to June $10^{\text {th }}$, 2019 in the health facilities of the Emana health area.

Results: A total of 64 healthcare providers participated in the study, 03 gynecologists and obstetricians, 10 General practitioners, 30 state-certified nurses, 09 midwives, 12 nursing assistants. The majority of these providers had poor knowledge of the causes of the disease (25\%), risk factors (34.4\%), and means of prevention (39.1\%), especially among state nurses (SRN), midwives, nursing assistants. (87.5\%) had good knowledge of the clinical signs of the disease and were almost unanimous on the curability of this disease when discovered early (78.1\%). The severity of the cancer was perceived by all; however, the practice of screening was low (10.9\%). As for their personal screening practices, $73.1 \%(38 / 52)$ of female staff had never been screened.

Conclusions: Even though the participants perceive the grave nature of the cervical cancer, the subsequent attitude and screening practices remain poor. The possible barrier to this is the insufficient continuous training and recycling of the health personnel. Emphasis should be laid on the methods of prevention of cervical cancer in the curricula of nurses and midwives in Cameroon.

Keywords: Attitudes, Care providers, Knowledge, Practices, Screening

\section{INTRODUCTION}

Cervical cancer is an infectious disease with a very high prevalence and morbidity especially in developing countries. It is the second most common cancer in the world with over 528000 new cases registered each year. It is also the fourth cause of death due to cancer (266 000 cases) in women worldwide. ${ }^{1}$ In Sub Saharan Africa, it is estimated that there are about 750000 new cases and 50 000 deaths every year due to cervical cancer. ${ }^{2}$
In Cameroon, cervical cancer $(23.9 \%)$ occupies the second position after breast cancer $(26.8 \%)$ and is affecting much younger women with time. According to the 2016 statistics from the Ministry of Public Health, about 14000 new cases of cancer are registered every year in our country with 1400 of them being cervical cancer and 2000 of them being breast cancer. Unfortunately, most of these registered cases have a fatal outcome. In Cameroon, of the 1400 to 1700 cases registered each year, 700 of them die every year. ${ }^{3}$ In spite 
of the fact that massive screening campaigns began in the late $90 \mathrm{~s}$, there is currently an increase in the prevalence and mortality due to cervical cancer within the general population. In Cameroon, the national coverage rate is unknown, and only 1 woman out of 200 is screened for the disease. ${ }^{4,5}$

The introduction of a cytologic test for screening of precancerous cervical lesions in the 1950s; the Pap smear brought about a breakthrough in some industrialised countries like Canada by decreasing to more than $50 \%$ the mortality rates due to cervical cancer. ${ }^{6}$ This is not the case in the developing countries where the coverage rate by screening tests is still in its embryonic stages despite the acute need for it. This is the case in Congo Brazzaville where cervical cancer is the most frequent cancer in women; in Cameroon where studies have shown that the knowledge attitudes and practices of Cameroonian women and health personnel concerning HPV (human papilloma virus) and cervical cancer are still very low. ${ }^{7-10}$ Research has shown that the attitude of health personnel and advice from them are strong determinants for the usage of screening tools by the population. ${ }^{11}$ It is in this light that we decided to carry out a survey to evaluate the knowledge, attitude and practices of health personnel in the Emana Health Area with respect to cervical cancer screening.

We intended by this study to consolidate the current achievements with regards to the fight against cervical cancer and inculcate new attitudes and practices in the health personnel while protecting the health of the female population; the ultimate beneficiaries of this study.

\section{METHODS}

This was a descriptive cross-sectional study in the Emana Health Area in Yaounde which is the biggest in the Djoungolo Health District. It is an urban region situated in the Yaounde I subdivision and is lodged between the Yaounde V, Yaounde II and Soa subdivisions. With a population of about 40000 inhabitants, it is stretched over a surface area of about $20 \mathrm{~km}^{2}$ and is bound to the North by Messasi, to the south by Etoudi and Nkolo mbong quarters, to the east by the central town and to the west by the Nkolondom quarter. The population has a good access to health care services with over 30 health care centers all organized around an Integrated Health Center. This study was carried over a period of 2 months from the $1^{\text {st }}$ of March 2019 to the $31^{\text {st }}$ April 2019 and over a duration of 6 months from $1^{\text {st }}$ February 2019 to the $31^{\text {st }}$ July 2019. The study population consisted of health care personnel, both male and female working in the Emana Health area.

\section{Inclusion criteria}

- Health care personnel working in the Emana Health area who accepted to participate in the study by giving their consent were included.

\section{Exclusion criteria}

- Health care personnel who were absent from their duty stations during the period of study were excluded from the study.

This study used a convenience sampling method while respecting the inclusion and exclusion criteria.

In a bid to respect the ethics of medical research, prior to starting this study we obtained administrative approval from the various authorities and also, this study obtained free and informed consent from the participants before their inclusion. Concerning the risk factors, we chose to consider the knowledge of at least two risk factors including HPV risk as a good level of knowledge. Concerning the knowledge of clinical signs of the disease, we choose to consider the knowledge of at least 2 criteria as good. As regards the means of prevention, we chose to consider the knowledge of at least 2 methods of prevention including screening as good.

\section{Statistical analysis}

The study data was collected using a pretested questionnaire and entered into a Microsoft excel 2013 workbook. We studied the distribution of study variables in line with this study objectives using Epi Infos version 7.2.2.6.

\section{RESULTS}

Table 1: Distribution of study population with respect to sociodemographic characteristics.

\begin{tabular}{|c|c|c|}
\hline Characteristics & Categories & $\begin{array}{l}\text { Frequencies } \\
\text { n }(\%)(N=64)\end{array}$ \\
\hline \multirow{4}{*}{ Age groups } & $<30$ & $12(18.7 \%)$ \\
\hline & $30-39$ & $28(43.7 \%)$ \\
\hline & $40-49$ & $11(17.2 \%)$ \\
\hline & $\geq 50$ & $13(20.3 \%)$ \\
\hline \multirow{5}{*}{$\begin{array}{l}\text { Professional } \\
\text { category }\end{array}$} & Gynaecologists & $3(4.7 \%)$ \\
\hline & General practitioner & $10(15.6 \%)$ \\
\hline & SRN & $30(46.9 \%)$ \\
\hline & Midwives & $9(14.1 \%)$ \\
\hline & NA & $12(18.7 \%)$ \\
\hline \multirow{2}{*}{ Sex } & Males & $12(18.8 \%)$ \\
\hline & Females & $52(81.2 \%)$ \\
\hline \multirow{4}{*}{$\begin{array}{l}\text { Work } \\
\text { experience } \\
\text { (years) }\end{array}$} & $0-5$ & $30(46.9 \%)$ \\
\hline & $6-10$ & $15(23.4 \%)$ \\
\hline & $11-15$ & $8(12.5 \%)$ \\
\hline & $\geq 16$ & $11(17.2 \%)$ \\
\hline
\end{tabular}

\section{Sociodemographic characteristics of health personnel}

A total of 64 health care personnel participated in the study; 3 gynaecologists, 10 general practitioners (GP), 30 state registered nurses (SRN), 9 midwives and 12 nurse aids (NA). The mean age of the participants was $37 \pm 9.45$ 
years (23 to 54 years). The most represented age group was the 30-40years age group $43.7 \%$, majority were women (52 giving $81.2 \%$ ), with a mean duration of work experience of $8.33 \pm 6.27$ years (range 1 to 22 years) (Table 1).

\section{Knowledge of health personnel concerning cervical cancer}

\section{Knowledge of the causes of cervical cancer}

All this study participants had heard of cervical cancer before. Only $45.3 \%$ declared knowing the cause of the disease and only $25 \%$ of the participants mentioned HPV as a cause of cervical cancer (Table 2).

Knowledge of risk factors and clinical signs of cervical cancer
This study noticed that $34.4 \%$ of the study population had a good knowledge of the risk factors of the disease. The distribution chart was topped by the gynaecologists and general practitioners who registered $100 \%$ and $80 \%$ respectively in terms of good knowledge, followed by the midwives, the SRNs and the NAs who registered 33.3\%, $23.3 \%$ and $8.3 \%$ in terms of good knowledge. Study also found that $87.5 \%$ of the study population had a good level of knowledge of the clinical signs of the disease. The distribution of the study participants with respect to their professional category and good knowledge of at least two clinical signs is shown in Table 3.

\section{Knowledge of the preventive nature of the disease}

A total $87.50 \%$ of the study population knew that the disease was preventable (Table 4).

Table 2: Knowledge of HPV as cause of cervical cancer.

\begin{tabular}{|llllll|l|}
\hline $\begin{array}{l}\text { Cause of } \\
\text { the disease }\end{array}$ & $\begin{array}{l}\text { Gynaecologists } \\
\mathbf{n = 3 / 3}(\%)\end{array}$ & $\begin{array}{l}\text { General practitioners } \\
\mathbf{n = 1 0 / 1 0}(\%)\end{array}$ & $\begin{array}{l}\text { SRN } \\
\mathbf{n = 1 0 / 3 0}(\%)\end{array}$ & $\begin{array}{l}\text { Midwives } \\
\mathbf{n = 3 / 9}(\%)\end{array}$ & $\begin{array}{l}\text { NA } \\
\mathbf{n = 3 / 1 2}(\%)\end{array}$ & $\begin{array}{l}\text { Total } \\
\mathbf{N}=\mathbf{6 4}\end{array}$ \\
\hline HPV & $3(100 \%)$ & $8(80 \%)$ & $3(10 \%)$ & $1(11.1 \%)$ & $1(8.3 \%)$ & $16(25 \%)$ \\
\hline Genetic & $0(0 \%)$ & $2(20 \%)$ & $7(23.3 \%)$ & $2(22.2 \%)$ & $2(16.7 \%)$ & $13(20.3 \%)$ \\
\hline Unknown & $0(0 \%)$ & $0(0 \%)$ & $20(66.7 \%)$ & $6(66.7 \%)$ & $9(75 \%)$ & $35(54.7 \%)$ \\
\hline Total & $3(100 \%)$ & $10(100 \%)$ & $30(100 \%)$ & $9(100 \%)$ & $12(100 \%)$ & $64(100 \%)$ \\
\hline
\end{tabular}

Table 3: Knowledge of the risk factors and clinical signs of the disease.

\begin{tabular}{|c|c|c|c|c|c|c|}
\hline Variables & $\begin{array}{l}\text { Gynaecologists } \\
\text { n=3 }\end{array}$ & General practitioners $\mathbf{n}=\mathbf{1 0}$ & $\begin{array}{l}\text { SRN } \\
n=30\end{array}$ & Midwives $\mathbf{n}=9$ & $\begin{array}{l}\text { NA } \\
n=12\end{array}$ & $\begin{array}{l}\text { Total } \\
N=64\end{array}$ \\
\hline \multicolumn{7}{|c|}{ Knowledge of at least 2 risk factors including } \\
\hline HPV & $3(100 \%)$ & $8(80 \%)$ & $7(23.3 \%)$ & $3(33.3 \%)$ & $1(8.3 \%$ & $22(34.4 \%)$ \\
\hline \multicolumn{7}{|c|}{ Knowledge of at least 2 clinical signs of cervical cancer } \\
\hline & $3(100 \%)$ & $10(100 \%)$ & $25(83.3 \%)$ & $9(100 \%)$ & $9(75 \%)$ & $56(87.5 \%)$ \\
\hline
\end{tabular}

Table 4: distribution of study participants with respect to knowledge of means of prevention.

\begin{tabular}{|lll|}
\hline Is cervical cancer preventable? & Number of participants & Percentages \\
\hline Yes & 56 & $87.6 \%$ \\
\hline No & 1 & $1.5 \%$ \\
\hline Don't know & 7 & $10.9 \%$ \\
\hline Total & 64 & $100 \%$ \\
\hline
\end{tabular}

Table 5: Distribution of the personnel with respect to their professional category and the knowledge of at least 2 methods of prevention.

\begin{tabular}{|lllllll|}
\hline Variables & $\begin{array}{l}\text { Gynaecologists } \\
\mathbf{n = 3}\end{array}$ & $\begin{array}{l}\text { General practitioner } \\
\mathbf{n = 1 0}\end{array}$ & SRN n=30 & $\begin{array}{l}\text { Midwives } \\
\mathbf{n = 9}\end{array}$ & NA $\mathbf{n = 1 2}$ & $\begin{array}{l}\text { Total } \\
\text { N=64 }\end{array}$ \\
\hline $\begin{array}{l}\text { Two methods } \\
\text { including HPV }\end{array}$ & $3(100 \%)$ & $7(70 \%)$ & $9(30 \%)$ & $3(33.3 \%)$ & $3(25 \%)$ & $25(39 \%)$ \\
\hline $\begin{array}{l}\text { Knowledge of 1 } \\
\text { method of prevention }\end{array}$ & $0(0 \%)$ & $3(30 \%)$ & $21(70 \%)$ & $7(66.7 \%)$ & $9(75 \%)$ & $39(61 \%)$ \\
\hline Total & $3(100 \%)$ & $10(100 \%)$ & $30(100 \%)$ & $10(100 \%)$ & $12(75 \%)$ & $64(100 \%)$ \\
\hline
\end{tabular}


Knowledge of the means of prevention of cervical cancer

Study found that $39.1 \%$ of the study population had a good knowledge of the means of prevention of cervical cancer.

The distribution of the personnel with respect to their professional category and the knowledge of at least two means of prevention showed that $100 \%$ of gynaecologists and $70 \%$ of general practitioners had a good knowledge followed by the midwives/M, the SRNs and the NAs as shown in Table 5.

Table 6: Distribution of the participants with respect to the perception of gravity of the disease.

\begin{tabular}{|lll|}
\hline Gravity of the disease & Number & Percentage \\
\hline Deadly & 43 & $67.2 \%$ \\
\hline Absence of treatment & 21 & $32.8 \%$ \\
\hline Total & 64 & $100 \%$ \\
\hline
\end{tabular}

Table 7: Distribution of the study population with respect to their professional category and the perception of the curable nature of the disease.

\begin{tabular}{|llllll|l|}
\hline $\begin{array}{l}\text { Professionnal } \\
\text { category }\end{array}$ & $\begin{array}{l}\text { Gynaecologists } \\
\mathbf{n = 3}\end{array}$ & $\begin{array}{l}\text { General } \\
\text { practitioners } \mathbf{n = 1 0}\end{array}$ & SRN $\mathbf{n = 3 0}$ & $\begin{array}{l}\text { Midwives } \\
\mathbf{n = 9}\end{array}$ & NA n=12 & Total N=64 \\
\hline Curable & & & & & & \\
\hline If discovered early & $3(100 \%)$ & $9(90 \%)$ & $23(76.7 \%)$ & $7(77.8 \%)$ & $8(66.7 \%)$ & $50(78.1 \%)$ \\
\hline Incurable & & $1(10 \%)$ & $6(20 \%)$ & $1(11.1 \%)$ & $2(16.7 \%)$ & $10(15.6 \%)$ \\
\hline Don't know & & & $1(3.3 \%)$ & $1(11.1 \%)$ & $2(16.7 \%)$ & $4(6.2 \%)$ \\
\hline
\end{tabular}

\section{Attitudes of health personnel regarding the disease}

Perception of the serious nature of the disease

Majority of the participants $43(67.2 \%)$ were aware that cervical cancer is a deadly disease and 21 (32.8\%) mentioned the lack of a definitive treatment for the disease (Table 6).

\section{Curable nature of the disease}

A total $78.1 \%$ of the study participants thought that cervical cancer was a curable disease if discovered early, $15.6 \%$ thought it was curable and $6.2 \%$ had no idea (Table 7).

Table 8: Distribution of personnel with respect to whether they prescribe screening tests.

\begin{tabular}{|lll|}
\hline $\begin{array}{l}\text { Prescription of a } \\
\text { screening test }\end{array}$ & Number & Percentage \\
\hline No & 57 & $89.1 \%$ \\
\hline Yes & 7 & $10.6 \%$ \\
\hline Total & 64 & $100 \%$ \\
\hline
\end{tabular}

\section{Practices of the health personnel regarding screening methods}

\section{Prescription of a screening test}

Majority of the participants $89.1 \%$ do not prescribe a screening test for cervical cancer (Table 8).

Past personal history of screening by the personnel
A total 14 participants $(26.9 \%)$ had undergone a screening test for cervical cancer (Table 9).

Table 9: Distribution of the participants with respect to their personal history of screening.

\begin{tabular}{|ll|l|}
\hline $\begin{array}{l}\text { Personal history } \\
\text { of screening }\end{array}$ & Number & Percentage \\
\hline No & 38 & $73.1 \%$ \\
\hline Yes & 14 & $26.9 \%$ \\
\hline Total & 52 & $100 \%$ \\
\hline
\end{tabular}

\section{DISCUSSION}

\section{Sociodemographic characteristics of the health personnel}

Of the 64 participants included, the mean age was $37 \pm 9$ with a range of 23 to 54 years. The most represented age group was the 30-39 years age group with $43.7 \%$ and a majority of them being female (81.2\%). The predominance of females can be explained by the fact that most nurses are females. In this study, majority of the participants were state registered nurses which is in concordance with data available from the ministry of public health after the general census of health personnel in 2015 which showed that about $50 \%$ of the health care workers are nurses. Furthermore, training schools for nurses are more available and affordable and so more health personnel tend to be trained as nurses. This study also revealed that $70.3 \%$ of the participants had less than or equal to 10 years of work experience with the greater majority being in the less than 5 years group. This could be explained by the fact that the older personnel with more years of service are usually not motivated to participate in surveys. Kouamo et al in Bamako found 
that $41.6 \%$ of their study participants had a work experience of less than or equal to 10 years. ${ }^{12}$

\section{Knowledge of health personnel on the disease}

A successful strategy for the eradication of a disease must involve a proper knowledge and understanding of the disease by the health care practitioners. Of the 64 participants who participated in this study, only $25 \%$ identified HPV infection as a cause of the cervical cancer. Their distribution with respect to their knowledge and professional category showed that gynecologists and general practitioners had a good knowledge of the disease compared to the nurses, midwives and nurse aids, This is in line with findings by McCarey et al in Cameroon who revealed that the level of knowledge of the disease was very low in midwives and nurses. ${ }^{9}$

Awareness of the risk factors is fundamental for an appropriate prevention of the disease. Study found that $100 \%$ of the gynecologists, $80 \%$ of GPs, $33.3 \%$ of midwives, $28.3 \%$ of SRNs and $8.3 \%$ of NAs representing a cumulative total of $34.4 \%$ of the health personnel had a good knowledge of the risk factors of cervical cancer. These risk factors are similar to the risk factors for bacterial and fungal gynecological infections which they encounter on a daily basis. These findings are similar to those observed by Twaha et al in Uganda where $40 \%$ of health professionals know risk factors. ${ }^{13}$

Concerning the clinical signs of cervical cancer, $100 \%$ of gynecologists, GPs and midwives; $83.3 \%$ of SRNs and $75 \%$ of NAs had a good knowledge and reported contact bleeding as a main sign. This is probably because most of the patients $(62.9 \%)$ reported to the hospital with advanced stages of the disease as reported by Sando et al. $^{14}$

Concerning the knowledge on the methods of prevention of cervical cancer, we found that $100 \%$ of gynecologists, $70 \%$ of GPs, $33.3 \%$ of midwives, $30 \%$ of SRNs and $25 \%$ of NAs had a good knowledge on the prevention of cervical cancer. The poor knowledge of means of prevention and screening especially in midwives, SRNs and NAs implies that health personnel cannot effectively fight against this pathology in our country since generalized screening campaigns are irregular and poorly followed up.

These results are different from those of Tchounga et al in Côte d'Ivoire where $42.4 \%$ of midwives had an appropriate knowledge on the prevention of cervical cancer. ${ }^{15}$ Nurses, midwives and nurse aids are usually the first line and most available personnel in most health care facilities and have a crucial role to play in the education of patients and the general population. Their lack of appropriate knowledge as depicted by this study highlights the urgent need for improvement of their knowledge concerning cervical cancer and it's preventable nature.

\section{Attitudes of health personnel with respect to the disease and screening methods}

The ability to adopt favorable attitudes when faced with a disease contributes enormously to its prevention and helps to protect those around us. $98.4 \%$ of the participants are aware that cervical cancer is a grave disease. !00\% of gynecologist, $98.3 \%$ of GPs, $94.4 \%$ of midwives, $89.16 \%$ of SRNs and $68.23 \%$ of NAs recognize that the disease is curable when diagnosed early. These results are relatively close to those by Kouamo in 2005 in Bamako who found that $100 \%$ of gynecologists, $95.62 \%$ of midwives, $80.76 \%$ of nurses who were aware that cervical cancer could be cured if it was diagnosed early and treated adequately. ${ }^{12}$ Twaha et al also found that majority of their participants knew that cervical cancer could be cured if it is diagnosed in the early stages. However, in this study, $2.4 \%$ of study participants had no idea of the curable nature of the disease which attests of their lack of information and training concerning the disease and also of the false information circulating about the disease.

\section{Practices of health personnel regarding screening methods}

Only $10.9 \%$ of the health personnel requested for a screening test whenever there were clinical signs suspicious of cervical cancer. This figure is alarmingly low especially considering the fact that the appearance of signs/symptoms attests of the advanced stage of the disease. The remaining $89.1 \%$ who do not request for a screening test justify their attitude by a lack of complaints from the patients. This clearly depicts the crucial lack of knowledge that the health personnel have concerning the slow evolution of the disease, the methods of prevention and the vital role they have to play in curbing the evolution of the disease. This lack of knowledge, the attitudes and practices of health care personnel can explain the reason why most often the disease is diagnosed in its advanced stages; cervical cancer arises as a failure in the screening mechanisms

A past history of prior screening is a protective factor against the onset and progression of precancerous cervical lesions. Women who have never undergone a screening test have a high risk of developing full blown cervical cancer. Screening by conventional Pap smear is recommended every two years and later on every three years if two previous tests were normal. According to study results, about $60 \%$ of the health personnel had never done a screening test before. Twaha et al while working in Uganda found that $81 \%$ of their study population had never undergone a screening test before. ${ }^{13}$ Nilaweera et al working in Sri Lanka also reported that $73.4 \%$ of female personnel had never done a screening test before. ${ }^{16}$ This unconcern on the part of the female health workers definitely has a negative impact on the level of sensitization of patients which is vital to enhance the preventive arm of the fight against this disease. 


\section{CONCLUSION}

This study showed that majority of the study participants had a good knowledge on the risk factors, clinical signs and curable nature of cervical cancer when diagnosed early enough. On the contrary, very few of them had a good knowledge of the means of screening and prevention. They also adopt an unfavourable attitude when it comes to sensitising and orientating patients for better management of the condition. Even though they perceive the grave nature of the disease, the subsequent attitude remains poor. The possible barrier to this is the insufficient continuous training and recycling of the health personnel. Emphasis should be laid on the methods of prevention of cervical cancer in the curricula of nurses and midwives in Cameroon.

\section{Funding: No funding sources}

Conflict of interest: None declared

Ethical approval: The study was approved by the Institutional Ethics Committee

\section{REFERENCES}

1. Organization Mondiale de la Santé. Dernières satisfies mandibles sur le cancer. Communiqué presse $\mathrm{N}^{\circ} 223$ du Centre international de recherche sur le cancer. CIRC. 2013:1-3.

2. Bouassa RM, Prazuck T, Lethu T, Meye J, Bélec L. Cervical cancer in sub-Saharan Africa: an emerging and preventable disease associated with human oncogenic papillomaviruses. Trop Med Health. 2017;27(1):16-22.

3. Tebeu PM, Sandjong DI, Nkele N, Fokoua S, Achu P, Kouam L. Pre-cancerous cervical lesions in rural areas: cross-sectional study. Med Af N. 2005;51:2731 .

4. Mbakop A, Essame Oyono JL. Ngbangako MC. Abondo A. Current epidemiology of cancers in Cameroon (Central Africa). Bulletin Cancer. 1992;79(11):1101-4.

5. Mbakop A, Yomi J, Yankeum J, Nkegoum B, Sone AM. Bulletin du cancer, Cancer localization in men and women aged over 50 in Cameroon. Bulletin du Cancer. 1997;84(12):1119-22.

6. Mantovani F, Massimi P, Banks L. The human papillomavirus E6 protein units contribution to malignant progression. Onc. 2001;20:7874-87.

7. Ngomo-Klutsch MJ, Belembaogo E, Diallo I. Clear cell adenocarcinoma of the cervix: a rare and aggressive form. Carcinol Prat Afrique. 2002;4:22-3.
8. Tebeu PM, Major AL, Rapiti E. The attitude and knowledge of cervical cancer by Cameroonian women; a clinical survey conducted in Maroua, the capital of Far North Province of Cameroon. Inter J Gynecol Cancer. 2007;18(4):761-5.

9. McCarey C. Pirek D. Tebeu PM. Boulvain M. Doh AS, Petignat P. Awareness of HPV and cervical cancer prevention among Cameroonian healthcare workers. BMC Womens Health. 2011;11:45.

10. Wamai RG, Ayissi CA, Oduwo G. Awareness, knowledge and beliefs about HPV, cervical cancer and HPV vaccines among nurses in Cameroon: An exploratory study. Inter $\mathbf{J}$ Nurs Stud. 2013;7489(12):00462-2.

11. Lurie N, Margolis KL, McGovern PG, Mink PJ, Slater JS. Why do patients of female physicians have higher rates of breast cancer and cervical cancer screening? J Gen Inter Med. 1997;12:34-43.

12. Kouamou EI. Knowledge, attitudes and practices of healthcare providers in BAMAKO related to cervical and breast cancer. Thesis Med. BAMAKO. Université de BAMAKO. 2005:100.

13. Mutyaba T, Mmiro FA, Weiderpass E. Knowledge, attitudes and practices on cervical cancer screening among the medical workers of Mulago Hospital, Uganda. BMC Med Educat. 2006;6(1):13.

14. Sando Z, Fouogue TJ, Fouelifack YF, Fouedjio JH, Mboudou ET, Essame OJ. L. Profile of gynecological and breast cancers in YaoundéCameroon. Pan African Med J. 2014;17(28):1-10.

15. Tchounga BK, Jaquet A, Coffie PA, Horo A, Sauvaget C, Adoubi I, et al. Cervical cancer prevention in reproductive health services: knowledge, attitudes and practices of midwives in Côte d'Ivoire, West Africa. BMC Health Serv Res. 2014; $14: 165$.

16. Nilaweera R, Perera S, Paranagama N, Anushyanthan AS. Knowledge and practices on breast and cervical cancer screening methods among female health care workers: A Sri Lanka experience. Asian Pac J Cancer Prevent. 2012;13:1193-6.

Cite this article as: Hortence FJ, Sophie MS,

Brigitte W, Florent FY, Charlette N, Ngaroua, et al. Knowledge, attitudes and practices of cervical cancer screening by health care providers in the Emana health area: Yaounde-Cameroon. Int J Reprod Contracept Obstet Gynecol 2020;9:2098-103. 